\title{
Mentoring for Entrepreneurs: A Boost or a Crutch? Long-Term Effect of Mentoring on Self-Efficacy ${ }^{1}$
}

\author{
Étienne St-Jean ${ }^{2}$ \\ Université du Québec à Trois-Rivières \\ Maripier Tremblay \\ Université Laval
}

\begin{abstract}
This study focuses on whether a mentor can facilitate the development of entrepreneurial self-efficacy, in particular with regard to opportunity recognition (ESE-OR) for novice entrepreneurs and whether their level of learning goal orientation (LGO) has a moderating effect. Based on a sample of 219 mentees and a longitudinal follow-up for 106 of these respondents, results show that mentoring supports the development of ESE-OR, but only for low LGO mentees. Furthermore, the effect of mentoring on ESE-OR for low LGO mentees is ephemeral, as it decreases once the relationship ends. This suggests the need for long-term support in order to maintain their ESE-OR high throughout the entrepreneurial endeavour. At the opposite end, high-LGO mentees see their ESE-OR slightly decline in an intense mentoring relationship, suggesting that mentoring helps to adjust ESE-OR to a more appropriate level for novice entrepreneurs.
\end{abstract}

Keywords: Entrepreneurial self-efficacy, Mentoring, Learning Goal Orientation, Opportunity recognition

\section{Introduction}

Novice entrepreneur mentoring appears to be a major triggering factor for entrepreneurial self-efficacy (St-Jean and Audet, 2013; Radu Lefebvre and Redien-Collot, 2013; Gravells, 2006; Ahsan et al., 2018). Based on social learning theory (Bandura, 1997; Bandura, 1986), vicarious

${ }^{1}$ Published online on February $17^{\text {th }}, 2020$, in International Small Business Journal. To get the published version: https://journals.sagepub.com/doi/10.1177/0266242619901058 
learning and verbal persuasion from mentors were identified as the most important contributions of the mentoring relationship in improving self-efficacy (Gordon and Brobeck, 2010; St-Jean et al., 2018). Despite the empirical and theoretical support of the effect of mentoring on selfefficacy, very few studies use longitudinal data to demonstrate this relationship, especially within an entrepreneurial setting. Thus, whether mentoring has a long- or short-term effect on selfefficacy, and the conditions under which this effect could be sustained, remain unknown.

Literature on mentoring highlights the fact that a mentee's learning goal orientation (LGO), a psychological disposition proposed by Dweck (1986), influences mentoring relationships by increasing mentee outcomes (Egan, 2005; Godshalk and Sosik, 2003), especially self-efficacy (Bell and Kozlowski, 2002; Culbertson et al., 2011). This disposition would also be important since it improves the potential entrepreneur's sense of feasibility (De Clercq et al., 2013) or venture progress (Uy et al., 2017). LGO (also referred to as mastery goal orientation) is a mind-set that interacts with failures or difficulties encountered in one's life (Dweck and Leggett, 1988; Elliott and Dweck, 1988; Diener and Dweck, 1978). As such, an individual with high LGO will be interested in mastering challenging tasks and work harder when faced with difficulties. An entrepreneurial career, with the many hurdles and difficulties that are encountered throughout the process of developing a business (Doern and Goss, 2014; Patzelt and Shepherd, 2011; Byrne and Shepherd, 2015), should attract individuals with high LGO, as it procures the challenges and continual learning opportunities they are looking for (Sullivan et al., 2007; Cope, 2005; Politis, 2005; Secundo et al., 2017). However, novice entrepreneurs with lower LGO may benefit more from their mentoring relationship, especially with regard to self-efficacy, as they

${ }^{2}$ Corresponding author: Etienne St-Jean, Université du Québec à Trois-Rivières, 3351, boul. des Forges, TroisRivières, QC G9A 5H7, Canada. Email: etienne.st-jean@uqtr.ca 
may rely more on external advice in order to gain confidence (through verbal persuasion and vicarious experiences). In contrast, those with high LGO may develop self-efficacy through mastery experiences; a process of trial and error. Therefore, entrepreneurs with low LGO should benefit more from their mentoring relationship, thus achieving a higher level of improved entrepreneurial self-efficacy (ESE).

The main goal of this study is to verify whether the mentoring received by a novice entrepreneur can help develop his/her ESE, as well as the potential moderating effect of LGO in this process. We first contribute by focusing on ESE as a major outcome of a mentoring relationship, rather than looking at other outcomes related to the business, such as growth or performance. As mentoring is more about developing the entrepreneur, on one hand, and ESE has been heavily investigated in the field of entrepreneurship as a key driver of entrepreneurial intention and action (Schmutzler et al., 2019), on the other hand, it seems more relevant to focus on this outcome. Furthermore, we analyse the effect of mentoring on ESE as part of a longitudinal research design. This is an important methodological improvement as very few studies use this design to investigate ESE (Newman et al., 2019). This methodology makes it possible to observe whether mentoring has a long-term effect on entrepreneurs. While LGO has been used in a few mentoring studies, it appears that the effect of this mind-set for novice entrepreneurs, and especially the potential moderating effect on the improvement of ESE through mentoring, have yet to be studied and represent another of our intended contributions. This adds to the investigation of the individual characteristics that could foster, or hamper, entrepreneurial support (Ciuchta et al., 2018), an area of mentoring research that has been overlooked (BanerjeeBatist et al., 2019). Lastly, while there is a new stream of studies that look at the effect of entrepreneurial support, especially mentoring and coaching, very few use mentor functions to 
assess the quality and depth of the mentoring relationship (Nabi et al., Online First). This way of investigating the effect of mentoring goes further than merely looking at the effect of the presence/absence of mentors (Ozgen and Baron, 2007).

Two types of analyses were carried out. Firstly, a cross-sectional analysis was done to test our hypotheses. To do so, we contacted entrepreneurs that were supported by a mentor in one of the larger Canadian mentoring schemes, of whom 219 agreed to complete our online survey. Secondly, a longitudinal analysis was carried out based on 106 respondents (of the 219) that agreed to participate in a follow-up three years later. This second analysis strengthened our findings and thus confirms our hypotheses with another research design. Both the cross-sectional and longitudinal analyses show the effect of mentoring on ESE and the moderating effect of LGO on the process. Furthermore, longitudinal results indicate that low LGO mentees lowered their ESE once they quit their mentoring relationship, highlighting the fact that the effect of mentoring on ESE is ephemeral. This suggests the need for longer-term support for low LGO individuals.

\section{Theory and Hypotheses}

\section{Entrepreneurial self-efficacy and mentoring}

Entrepreneurial mentoring involves pairing up a novice entrepreneur with an experienced one, who provides advice and ways of thinking to help the novice avoid costly and even fatal mistakes (Sullivan, 2000; St-Jean and Audet, 2012; Gravells, 2006). Extant empirical research (Ozgen and Baron, 2007; St-Jean and Audet, 2012) highlights the positive cognitive effects

(identifying opportunities, clarifying business vision, developing skills, etc.) and affective learning outcomes (reducing uncertainty and isolation, improving self-efficacy, establishing more ambitious goals, etc.) of mentoring relationships. Public organisations have implemented 
programmes to support entrepreneurs during the first years of their business start-up; mentoring is part of such programmes. While some programmes aim to provide support to university students who intend to become entrepreneurs (Eesley and Wang, 2017) or to start-ups (Brodie et al., 2017), others are part of incubator/accelerator bundled services (Lukosiute et al., 2019), sometimes oriented to specifically support technopreneurship (Kornelsen, 2018). However, many programmes are open to novice entrepreneurs in general (St-Jean et al., 2018). Although mentoring is mainly carried out in a face-to-face dyadic setting, other mentoring configurations can be offered to entrepreneurs (or other people), like peer mentoring (Kubberød et al., 2018), or e-mentoring (Singh and Kumar, 2019). Given that the context in which mentoring develops and is directed is important, and that it varies greatly from one study to another, it is imperative to set the boundaries in order to understand its expected impact.

There are also various other types of support that are related to the term "mentoring" (D'Abate et al., 2003). As such, some discrepancies may exist between what mentoring should be from a theoretical standpoint, and what it actually reveals to be as a practice, raising confusion about the expectations related to this kind of support (Garvey, 2004). Mentoring derives from Homer's Odyssey, where the hero Odysseus entrusts his son Telemachus to his friend Mentor while he is away at war. Inspired by Greek mythology, a mentor is generally a person who possesses certain qualities or is in a position of authority, and who kindly watches over a younger individual so that he or she may benefit from the mentor's support and advice. Mentoring support occurs in different contexts, for example and without limitations, in supporting disadvantaged youth (Preston et al., 2019), students at risk (Heppen et al., 2018), people entering challenging careers such as nursing (Williams et al., 2018) or teaching (Talbot et al., 2018) or more generally, in any kind of organisation that aims to develop its workforce (Ghosh et al., 2019). In an 
entrepreneurial context, although other definitions are possible, mentoring is a support relationship between a novice entrepreneur (where lack of experience is key), referred to as a "mentee," and an experienced business person, referred to as a "mentor," where the latter helps the former develop as a person. To recognise a mentoring relationship as distinct from other types of support, three components must be present: there must be a reciprocal relationship with development benefits for the mentee, especially career-related benefits, as well as regular and substantial interaction with a long-term perspective (Haggard et al., 2011).

This study is about mentoring in a stand-alone dyadic, face-to-face, formal programme that involves benevolent, experienced business people who are interested in giving back to their community through the support they provide to novice entrepreneurs. This kind of programme would normally result in personal and professional developmental outcomes, mainly rooted in learning. The theoretical framework of this paper is based on social cognitive learning theory (Bandura, 1986), in which the specific concept of self-efficacy is rooted, and on goal orientation theory (Dweck and Leggett, 1988; Elliott and Dweck, 1988). Firstly, self-efficacy refers to the personal perception of one's ability to successfully accomplish a specific task or behaviour (Bandura, 1997). Individuals with a high level of self-efficacy tend to perceive difficult tasks as challenging and not as something that should be avoided. According to Bandura (1997: 77), selfefficacy beliefs are constructed from four principal sources of information: 1-Enactive mastery experiences that serve as indicators of capability; 2-Vicarious experiences that alter efficacy beliefs through transmission of competencies and comparison with the attainments of others; 3 Verbal persuasion and allied types of social influences that one possesses certain capabilities; and 4-Physiological and affective states from which people partly judge their capability, strength, and vulnerability to dysfunction. 
In a mentoring relationship context, mentors can be a crucial source of information (Ozgen and Baron, 2007; Nowiński and Rialp, 2016) allowing mentees to strengthen their entrepreneurial self-efficacy. If mentoring does not seem to support entrepreneurial self-efficacy development through enactive mastery experiences, indirect evidence obtained from previous research suggests that mentoring can develop self-efficacy through the other three processes (vicarious experiences, verbal persuasion, and physiological and emotional states) (ref. Bandura, 1997). Indeed, mentors can support self-efficacy development through vicarious experiences in becoming role models, allowing mentees to evaluate and improve their entrepreneurial and business skills through social comparison and imitative behavioural strategies (BarNir et al., 2011; Johannisson, 1991; McGowan et al., 2015; Baluku et al., 2019). Mentors can also systematically use verbal persuasion strategies to help mentees explore, and sometimes change, their attitudes and beliefs (Radu Lefebvre and Redien-Collot, 2013; St-Jean and Audet, 2013; Marlow and McAdam, 2012; Brodie et al., 2017). Lastly, mentors can influence the mentees' emotional state by reducing their perceived uncertainty and stress concerning future challenges (Kram and Hall, 1989; Sosik and Godshalk, 2000).

From a methodological standpoint, Bandura (1997) stressed that specific measures should be designed so as to enable researchers to assess self-efficacy in particular contexts. Bandura also highlighted the importance of developing task-specific scales. Following this recommendation, entrepreneurship scholars have identified various work-related tasks and developed specific selfefficacy scales that have the capacity to detect business opportunities, build and convey entrepreneurial visions, set business goals, manage staff and deal with financial issues (Anna et al., 2000; DeNoble et al., 1999; McGee et al., 2009). Entrepreneurial self-efficacy in opportunity recognition (ESE-OR) may be the most relevant dimension in studying novice entrepreneurs. 
First, individuals with high self-efficacy (and optimism) are more likely to exploit opportunities because it requires them to act amid everybody else's scepticism (Shane and Venkataraman, 2000; Ardichvili et al., 2003). It is also suggested that entrepreneurs with high self-efficacy believe they can be successful at pursuing an opportunity regardless of the environment (Mitchell and Shepherd, 2010; Schmitt et al., 2018). They also believe they can persist when committed to a failing course of action (Whyte et al., 1997), highlighting the importance of entrepreneurial action. Just as fear is a negative emotion that prevents the exploitation of opportunities (Welpe et al., 2012), having a strong sense of one's ability to succeed should trigger the exploitation phase. Entrepreneurial mentoring has a recognised impact on opportunity exploitation (McKevitt and Marshall, 2015). Experienced entrepreneurs are also able to identify more opportunities than novices (Ucbasaran et al., 2009; Baron and Ensley, 2006; Baron, 2006), and the entrepreneur's experience and human capital are related to the firm's performance (Unger et al., 2011; Chandler and Hanks, 1994), specifically through opportunity recognition self-efficacy (Dimov, 2010; Ramos-Rodriguez et al., 2010). Thus, ESE-OR may act as a proxy for assessing entrepreneurial capacity in opportunity recognition. Furthermore, as was mentioned above, ESE-OR is particularly important in predicting the success of newly established firms (Dimov, 2010) as well as real opportunity recognition (Ozgen and Baron, 2007). Based on Bandura's recommendation, we focused specifically on ESE-OR, as it appears to be one of the most relevant dimensions of ESE for studying novice entrepreneurs.

If it is recognised that a mentor can influence self-efficacy, all mentors do not have the same level of influence: some may only provide marginal mentoring (Ragins et al., 2000) or worse, harmful mentoring experiences (Eby et al., 2004; Simon and Eby, 2003; Eby et al., 2000). The quality and depth of mentoring relationships can be assessed by mentor functions (Kram, 
1985; Nabi et al., Online First), as they allow mentees to benefit from the mentoring relationship in various ways, particularly in terms of positive changes regarding their self-efficacy (Day and Allen, 2004; Powers et al., 1995; Wanberg et al., 2003) or, more generally, on their career development (Jyoti and Sharma, 2015; Park et al., 2016). Generally speaking, mentor functions studied in large organisations are grouped into three categories: psychological, career-related, and role-model functions (Bouquillon et al., 2005; Pellegrini and Scandura, 2005; Scandura and Williams, 2001). Previous studies on mentoring for entrepreneurs used samples with portions that did not have any mentors, as they were looking at the effect of mentoring (Ozgen and Baron, 2007). However, as we are not interested in looking at the effect of having a mentor, but rather the effect of mentoring itself, which involves assessing the quality of the relationship (Ting et al., 2017), considering mentor functions is helpful in that regard. Mentor functions assess the depth and strength of the mentoring received, and thus act as a proxy measure for the quality of the relationship. Knowing that providing mentor functions throughout a mentoring relationship is most likely to develop the mentee's self-efficacy, we suggest the following hypothesis:

Hypothesis 1: Mentor functions have a positive effect on the mentee's entrepreneurial self-efficacy in opportunity recognition (ESE-OR)

\section{Learning goal orientation and mentoring}

Goal orientation theory presents the general view that an individual chooses to approach a task, complete the task, and evaluate his or her performance on that task (Pintrich, 2000; Dweck and Leggett, 1988; Elliott and Dweck, 1988). Goal orientation should not be mistaken with taskspecific goals (Locke and Latham, 1990), as the latter explains the what about goals, whereas the former explains the why and how (Pintrich, 2000). Learning goal orientation (also referred to as mastery goal-orientation) is a relatively stable psychological disposition that individuals mobilise 
in their relationships with others (Dweck, 1986). Individuals with high LGO tend to perceive their competencies as malleable and subject to change (Dupeyrat and Mariné, 2005). These individuals therefore approach the tasks at hand with self-confidence and willingness to develop their skills. They consequently value hard work and self-improvement and constantly look for new challenges to enhance their skills (Dweck and Leggett, 1988). By doing so, they engage in new activities, regardless of difficulty, wishing to learn new things and improve their abilities (Button et al., 1996). Individuals with low LGO, on the other hand, tend to see their intelligence and skills as 'stable' and 'unchangeable.' They also tend to have a lower sense of self-efficacy than those who perceive their skills as malleable (Ames, 1992).

In a study that investigates children's behaviour after an academic failure, Diener and Dweck (1978) found that learning-oriented children make fewer attributions and focus on solutions in order to avoid failure, while helpless children (i.e. low learning goal orientation) focus on the cause of failure. In school, students who adopt or endorse LGO (or mastery goalorientation) engage in more self-regulated learning than others (Pintrich and Schunk, 1996; Ames, 1992). Furthermore, the LGO mind-set, also referred to as a "growth mind-set" (Dweck, 2008), has been shown to be related to high intrinsic motivation (Haimovitz et al., 2011), goal achievement (Burnette et al., 2013) and self-efficacy (Ames, 1992; Uy et al., 2017). It has also been found that an entrepreneurial career anchor can be explained by the combined effect of high general self-efficacy with high LGO, suggesting that both variables act together in influencing the choice of becoming an entrepreneur (Culbertson et al., 2011). Furthermore, perception of abilities in entrepreneurship (referring to self-efficacy), combined with LGO as moderator, explain entrepreneurial intention in students (De Clercq et al., 2013). Therefore, we assume that individuals with a high level of learning goal orientation also have a high level of entrepreneurial 
self-efficacy based on the clear influence the former has on the latter, especially on (potential) entrepreneurs. These considerations lead us to the following hypothesis:

Hypothesis 2: Mentees' learning goal orientation is positively related to their entrepreneurial self-efficacy in opportunity recognition (ESE-OR).

Of course, an entrepreneurial career is likely to bring many intellectual challenges and obstacles that demand regular attention and behavioural flexibility. With the many hurdles and difficulties that are encountered throughout the process of developing a business (Doern and Goss, 2014; Patzelt and Shepherd, 2011; Byrne and Shepherd, 2015), this type of career should attract individuals with high LGO. Entrepreneurs with high LGO will be stimulated by those challenges and consider them as opportunities to develop their intelligence and skills (Ames and Archer, 1988). LGO is associated with feedback-seeking behaviour (VandeWalle, 2004; Tuckey et al., 2002; VandeWalle and Cummings, 1997). Mentoring should attract entrepreneurs with high LGO, as it provides feedback within a career setting that does not include assessment from hierarchical superiors. Novice entrepreneurs who engage in mentoring relationships implicitly acknowledge that they need the mentors' support to achieve their career-related goals. Mentees may thus consider their mentors as a potential learning source (Sullivan, 2000; St-Jean and Audet, 2012). We suppose that novice entrepreneurs who perceive their intelligence as stable (low learning goal orientation) may feel the need for external support when faced with difficult tasks. The need for external help may be stronger for those individuals who believe themselves to be incapable of improving their abilities. These individuals may experience greater benefits and appreciate mentoring relationships to a greater extent than those who are more learning oriented, and thus inclined to rely on their own capacity to face difficulties by improving their skills. Even 
though high learning goal orientation can attract entrepreneurs in a mentoring scheme, those with low learning goal orientation, who despite choosing to be supported by a mentor, should benefit even more from their mentoring relationship, especially in terms of self-efficacy development. These considerations suggest the following hypothesis:

Hypothesis 3: The mentees' learning goal orientation has a negative moderating effect on the relationship between mentor functions and the mentees' entrepreneurial self-efficacy in opportunity recognition (ESE-OR). More specifically, low LGO mentees will improve their ESE-OR with the mentor functions, while high LGO mentees will not improve their ESE-OR.

\section{Methodology}

\section{Programme under study}

We collected data through Réseau $M$ - a business-mentoring programme created in 2000 by the Fondation de l'entrepreneurship - an organisation dedicated to economic development in the Province of Québec (Canada). It is offered to novice entrepreneurs through a network of 70 mentoring cells spread out across the province. These cells are generally supported by various economic development organisations such as local development centres (LDC's), Community Futures Development Corporations (CFDCs), and local chambers of commerce. These organisations ensure the local or regional development of the programme, while subscribing to the business-mentoring model developed by the Fondation. More specifically, local organisations employ a cell coordinator in charge of recruiting mentors, organising training sessions for them, promoting the programme to novice entrepreneurs, pairing participants, and supervising the ensuing mentoring relationship. In most cases, mentees choose their mentor. They are aware that 
both dyad members should be willing to work together. Novice entrepreneurs can benefit from mentor support for a minimal cost of a few hundred dollars per year, and in some cases free of charge. In order to properly supervise local development, the Fondation provides development workshops on mentor-mentee relationships to give novice entrepreneurs a clear idea of the mentor's role. Based on an intervention code of ethics, where relationship confidentiality is of capital importance, the business-mentoring programme has also created a standard contract to guide the parties in determining the terms and conditions of their relationship, and the desired objectives. Therefore, this programme is a formal type of mentoring.

\section{Sampling procedure}

The population under study is a group of mentored entrepreneurs from the businessmentoring programme who have had at least three meetings with their mentor, or who are still in a mentoring relationship, and who had a valid email address (981 individuals). In 2008, mentees were invited to take part in the study via email, and two follow-ups were carried out with the nonrespondents, resulting in a total of 360 participants. This gave us a response rate of $36.9 \%$. Since a portrait of the population was not available at that time, a comparison was made with the early respondents (who replied the first time) and later respondents (after follow-ups), as suggested by Armstrong and Overton (1977). No significant differences were found between demographic variables, business-related variables, or those measured in this study. This suggests that the sample would likely represent the population under study. It should be noted that, in further analysis of this sample, we retained only respondents who completed the questionnaire in its entirety, lowering the sample to 219 individuals to test our hypotheses. 
The initial sample consisted of $162^{3}$ men $(51.6 \%)$ and 152 women $(48.4 \%)$. They were paired with 275 male mentors (81.4\%) and 63 female mentors (18.6\%). This situation is deemed to be "normal" considering the large representation of men among available mentors, probably due to historical factors: there were fewer women in business twenty to forty years ago than today (Stevenson, 1986). Consequently, the pool of potential female mentors is more limited. Mentees have more education than the general population, since $173(55 \%)$ of them have university degrees. The average age is 39.8 (standard deviation of 8.97) and varies between 23 and 70. At the time of the start-up, 24\% had no experience in their business' industry, 33.2\% had fewer than one year, $46.2 \%$ had fewer than three years, and $61.6 \%$ had fewer than five years. As for business experience, the majority (51.1\%) had no experience, $63.4 \%$ had fewer than one year, $73.6 \%$ had fewer than three years, and $82.9 \%$ had fewer than five years. Almost all mentees had an active business at the onset of the pairing (293 out of $314,93.3 \%)$ and the others were at the start-up process. Businesses had few employees, with an average of 4.48 (standard deviation of 9.69 , median of 2$)$. Business turnover was mainly under $\$ 100,000 \mathrm{CAD}$ annually $(62.8 \%), 88.9 \%$ had an annual turnover of less than $\$ 500,000$, and only $8.6 \%$ exceeded $\$ 1$ million. As for gross profits, including salaries and bonuses for heading the business, the situation is just as grim. The vast majority (68.1\%) declared annual profits below $\$ 25,000,83.5 \%$ made less than $\$ 50,000$ and only $6.3 \%$ made more than $\$ 100,000$. Industry sectors are varied, with a slight concentration in professional services $(62$, for $23.0 \%)$, manufacturing (39, for $14.4 \%)$ and retail (32, for $11.9 \%)$. Mentoring relationships lasted 16.07 months on average (standard deviation of 14.4, median of 13). Meetings with the mentor lasted 68.52 minutes on average (standard deviation of 14.4,

\footnotetext{
${ }^{3}$ The sum is not always equal to 360 because of the non-respondents to some questions. This also occurs in the regression analysis.
} 
median of 67), and there were a little less than one meeting per month (0.807), with the median at one meeting per month. The majority of respondents were still in their mentoring relationship at the time of the survey $(58.6 \%)$.

Three years later (Time 2), a survey follow-up was conducted among the mentees at Time 1 survey ( $n=197)$ who had expressed the desire to be contacted in the future. Among them, 103 agreed to answer the online survey. In this follow-up, we examined the progress of the mentoring relationship and measured the evolution of certain variables over time, in particular entrepreneurial self-efficacy in opportunity recognition, as measured at Time 1 (see the "dependent variable" in the "measures" section below). This data collection is used for the longitudinal analysis.

\section{Attrition bias estimation}

Unfortunately, we were unable to access all the respondents from the baseline sample (Time 1). One may argue that attrition (i.e. loss of respondents in a longitudinal study) may have distorted the findings, since those who answered the survey in the follow-up (Time 2) are more likely to be better performers, just as other biases may affect the likelihood of participation in the second wave. In order to assess this potential bias, we followed Goodman and Blum's (1996) recommendation. We compared the profile of respondents who answered only the first wave (Time 1 only) with those who answered both waves (Time 1 and Time 2) regarding sociodemographic dimensions (gender, age, education), business characteristics (sales, number of employees, profits), and the main variables of this study (LGO and ESE-OR). We also performed a binary logistic regression to estimate the probability of participating in the follow-up using those variables (LGO and ESE-OR) as predictors, a procedure also suggested by Goodman and Blum (1996). We did not find any significant differences between the two groups ( $t$ test), except 
for the level of education. The respondents who answered both waves have a little more education. This is similar to other longitudinal studies (Spoth et al., 1999; Korkeila et al., 2001), since respondents with more education are probably more inclined to be drawn towards new knowledge creation by researchers. However, this difference should not influence the final results. Furthermore, neither LGO nor ESE-OR can predict the probability of being part of the 2nd wave survey. Therefore, attrition bias does not seem to affect our data.

\section{Measures}

Dependent variable. To measure entrepreneurial self-efficacy in opportunity recognition, we used the scale developed by Anna et al. (2000). It includes 3 items on a 7-point Likert scale: 1-I can identify the unmet needs of the market, 2-I can recognise products that will succeed, 3-I can recognise opportunities. The exploratory factor analysis revealed unidimensionality $(81.07 \%$ of explained variance) and a Cronbach's alpha of 0.882 , which is well above average (Tabachnick and Fidell, 2007). Since the construct is empirically adequate, we created a measure using the mean of all items. The same measure was used in the follow-up study (Time 2).

Independent variables. The measure used for learning goal orientation is the one developed by Button et al. (1996) which includes 8 items computed on a 7-point Likert scale, ranging from 1-“Strongly disagree" to 7-“Strongly agree." Items measure the mentee's disposition towards learning situations, such as: "Having the opportunity to accomplish a challenging task is important to me," or "When I am unable to accomplish a difficult task, I demand more from myself the next time." Other studies have used this measure with good results in terms of unidimensionality and internal consistency (Godshalk and Sosik, 2003). The confirmatory factorial analysis (CFA) indicates that all items are significant in explaining the latent variable. The fit indices for the confirmatory model are excellent, with an $\chi^{2}$ of 23.0012 for 
17 degrees of freedom $(p=0.1492)$, RMSEA of 0.03721 , SRMR of 0.03492 , CFI of 0.9979 , and NFI of 0.9921. Cronbach's alpha is 0.927. This measure is therefore acceptable for the subsequent analysis and we computed the variable mean.

In regards to mentor functions, we selected nine items from the scale developed by StJean (2011), one for each function, and incorporated the highest coefficient of each proposed construct (see Table 1). The scale measures mentor functions as a whole and assesses the quality and depth of the relationship. Items were recorded on a 7-point Likert scale, from 1-"Strongly disagree" to 7-“Strongly agree." The confirmatory analysis of this mentor function measure using LISREL showed that all items are significant to $p \leq 0.01$ in explaining the latent variable. Furthermore, $\chi^{2}$ is 36.29 for 27 degrees of freedom $(p=0.10908)$, RMSEA is 0.04667 , SRMR is 0.03780 and CFI is 0.9959 , which confirms that it is an excellent model for assessing the mentor functions. Cronbach's alpha for the nine items is 0.898 , which is above standards (Tabachnick and Fidell, 2007). We thus created a measure using the mean of all items for the subsequent analysis.

\section{Table 1}

Mentor Functions (based on St-Jean (2011) scale)

\begin{tabular}{ll}
\hline \multicolumn{1}{c}{ Item } & \multicolumn{1}{c}{ Wording } \\
\hline Reflector & My mentor enables me to construct a precise image of myself and my business \\
Reassurance & My mentor reassures me \\
Motivation & My mentor believes I can succeed as an entrepreneur \\
Confidant & My mentor is considered a friend \\
Integration & My mentor puts me into contact with people he/she knows \\
Inform.support & My mentor supplies information about the business world \\
Confrontation & My mentor does not hesitate to oppose when he/she disagrees with me \\
Guide & My mentor suggests other points of view \\
Role model & My mentor shares his/her successes and failures with me \\
\hline
\end{tabular}


Control variables. As previously suggested, control variables should not be added to "purify" the analysis (Spector and Brannick, 2011). Only the variables recognised as interfering with the dependent variable, or that could theoretically have an effect, should be controlled for. There are certain exogenous variables that can have an impact on entrepreneurial self-efficacy, such as the respondents' gender (Mueller and Dato-On, 2008; Wilson et al., 2009) and age (Maurer, 2001). Knowledge and information acquired through previous work experience improve the ability to identify opportunities (Shane, 2000; Shepherd and DeTienne, 2005) and are also related to opportunity recognition self-efficacy (Dimov, 2010). Tacit knowledge, particularly when acquired through management experiences, may also improve opportunity recognition (Ardichvili et al., 2003; Davidsson and Honig, 2003). General levels of education also have this effect (Davidsson and Honig, 2003; Arenius and Clercq, 2005). We also used the mentor's gender as a control variable since it can influence the mentoring process and outcomes (Levesque et al., 2005). Lastly, we controlled for the mentor's experience as an entrepreneur, just as for mentor's industry sector $(0=$ same industry sector as mentee, $1=$ different industry sector than mentee), since role modelling can affect entrepreneurial self-efficacy (BarNir et al., 2011).

\section{Common method bias}

Using self-reported data, measuring both predictors and dependent variables, may result in common method variance (CMV) (Podsakoff et al., 2003). To minimise the possibility of CMV, we used many recommended a priori remedies (confidentiality, ordering of dependent and independent variables, etc.). Also, our data uses longitudinal samples, which eliminates all possible contamination between data collection. Moreover, we performed Harman's single factor test as a post-hoc test. This procedure involves conducting an unrotated exploratory factor analysis on all of the items collected for this study. Results indicate that our data converge into 
three factors (one for each measure used), and that the first one explains only $28.55 \%$ of the variance. Furthermore, our data shows low correlations, or no correlation at all, between our main variables (see Table 2. For example, no correlation between LGO and mentor functions). This is unlikely to appear in data contaminated with CMV. Moreover, when the variables are too complex and cannot be anticipated by the respondent, as observed in this study, this reduces the potential effects of social desirability and therefore reduces the common method bias (Podsakoff et al., 2003). In addition, when the measured variables concern the respondents' personality, as for LGO, this is not necessarily a limitation, as it is impossible to measure otherwise (Spector, 2006). All combined, this strongly suggests that risks of CMV are minimised.

\section{Analysis}

To test the hypotheses, we used a hierarchical regression analysis using ESE in opportunity recognition as the dependent variable. In the first model, control variables related to the mentee were introduced. In the second, we added control variables pertaining to the mentor. We integrated mentee learning goal orientation into the third model, and mentor functions into the fourth. The final model included the interaction between mentor functions and LGO. We calculated the interaction between mentor functions and mentee learning goal orientation by multiplying the concerned variables and mean-centering the results for a better interpretation of the coefficients. As previously mentioned, we retained only the respondents that answered every question, with a result of $n=219$.

In addition, for the second hypotheses confirmation step, we verified the evolution of ESE in opportunity recognition (dependent variable) over time (three-year period), based on the progress of the mentoring relationship. We used GLM for repeated measures to assess the changes in the mean for the variables over time. In this research design, it was difficult to control 
for the mentoring received (i.e. mentor functions) at follow-up, given that some mentoring relationships had ended at the time of the initial survey. Consequently, for those who stopped their relationship before the baseline survey (Time 1), mentor functions were no longer relevant in the follow-up three years later (Time 2). Nevertheless, we can compare those who stopped their relationship before Time 1 with those who were in their relationship at that moment and continued to work with their mentor over the following months/years. Despite the fact that the pre-test/post-test design would have been best to study the impact of starting a new relationship, this is almost impossible to put into application in real life, since anyone seeking a mentor does not want to see the relationship delayed for research purposes. Thus, as we assessed many relationships that had already started, the best possible research design was to investigate the effect of terminating the support from a mentor. As such, we have a pre-test/post-test design directed at studying the impact of stopping the relationship.

The mentoring effect would probably occur within a year of the initial pairing. Since we had two control points set in time (Times 1 and 2), we divided the respondents into two groups: those whose relationships were active at Time $1(n=59)$ and those whose relationships were over $(\mathrm{n}=44)$. Among those whose relationships were active at Time $1(\mathrm{n}=59)$, it is noteworthy that 8 relationships ended within a year, 17 the following year, another 17 in the year after that, and only 2 at Time 2, leaving 15 that were still active during the survey follow-up (Time 2), with no clear indication that they were about to stop.

We ran a GLM for repeated measures analysis to assess the impact over time of still being in a relationship with a mentor compared with others who had stopped. We controlled for variables that could have an impact on ESE-OR, namely age, education, experience as well as mentor functions. Instead of calculating the interaction between mentor functions and LGO, we 
considered the interaction between LGO and stopping the relationship with the mentor to further test our hypotheses with the longitudinal design. Indeed, as previously mentioned, because some relationships stopped before 2008, mentor functions were no longer a relevant concept for them and would therefore only be controlled for in the analysis. We also created a dummy variable based on the mentees' LGO levels to create two groups separated at the median (low/high LGO) in order to facilitate the analysis and interpretation. The procedure for GLM for repeated measures creates an interaction graph for every single level of LGO, making the interpretation almost impossible without separating mentees at the median for high or low LGO.

\section{Results}

\section{Cross-sectional analysis}

Table 2 illustrates the means, standard deviations and variable correlations for this study.

\section{Table 2}

Means, Standard Deviation and Correlations ${ }^{1}$ of Variables

\begin{tabular}{|c|c|c|c|c|c|c|c|c|c|c|c|c|c|}
\hline Variable & Mean & S.D. & 1 & 2 & 3 & 4 & 5 & 6 & 7 & 8 & 9 & 10 & 11 \\
\hline 1- Mentee's gender ${ }^{\mathrm{a}}$ & 0.48 & 0.50 & 1.00 & & & & & & & & & & \\
\hline 2-Age & 39.81 & 8.97 & -.01 & 1.00 & & & & & & & & & \\
\hline 3-Education & 2.53 & 0.94 & .12 & .08 & 1.00 & & & & & & & & \\
\hline 4-Industry experience & 3.35 & 1.62 & -.01 & .05 & -.10 & 1.00 & & & & & & & \\
\hline 5-Management experience & 2.29 & 1.56 & -.13 & .25 & -.09 & .19 & 1.00 & & & & & & \\
\hline 6-Mentor experience ${ }^{b}$ & 0.48 & 0.50 & -.03 & -.16 & -.11 & .02 & -.09 & 1.00 & & & & & \\
\hline 7-Industry dyad ${ }^{\mathrm{c}}$ & 0.81 & 0.40 & -.04 & .01 & -.03 & -.02 & -.06 & -.01 & 1.00 & & & & \\
\hline 8-Mentor's gender ${ }^{\mathrm{a}}$ & 0.19 & 0.39 & .33 & .00 & -.02 & .03 & .02 & .01 & -.06 & 1.00 & & & \\
\hline 9-LGO & 6.24 & 0.88 & .12 & -.05 & -.02 & -.03 & .04 & .02 & .01 & .02 & 1.00 & & \\
\hline 10-Functions & 5.39 & 1.15 & .06 & -.14 & .00 & .00 & -.03 & .07 & .03 & .09 & .01 & 1.00 & \\
\hline 11-Opportunity recognition & 5.75 & 1.00 & -.04 & -.24 & -.04 & .05 & .08 & .02 & -.03 & -.02 & 0.23 & 0.15 & 1.00 \\
\hline
\end{tabular}

${ }^{1}$ Correlations $\geq 0.12$ are significants at $p \leq 0.05$

${ }^{\text {a }}$ Men $=0$, Women $=1$

${ }^{\mathrm{b}}$ Non-entrepreneur $=0$, entrepreneur $=1$

${ }^{c}$ Same industry $=0$, Different industry $=1$ 
As seen in Table 3, age had a negative influence on the dependent variable, whereas management experience had a positive effect. Other variables were non-significant at $p \leq 0.05$ $\left(\operatorname{adj} . R^{2}=0.083\right)$. In the second step, we entered variables related to the mentor. For mentors, having experience as an entrepreneur, or being in a different industry, does not influence opportunity recognition (ESE-OR) by the novice. In the third step, LGO was entered, which had a positive influence on the dependent variable $\left(\operatorname{Std} \beta=0.237, \Delta\right.$ adj. $\left.R^{2}=0.051\right)$ and remained significant at $p \leq 0.001$ in Model V (H2 confirmed). For the fourth step, mentor functions had a positive effect on the mentee's self-efficacy in recognising opportunities ( $\left.\Delta \operatorname{adj} . R^{2}=0.023\right)$, and remained significant in Model V (Std $\beta=0.197, p \leq 0.01)$ (H1 confirmed). In the last step, we added the interaction term of LGO X mentor functions, which was significant at $p \leq 0.001$ and had a negative effect (Std $\beta=-0.247, \Delta$ adj. $\left.R^{2}=0.056\right)(\mathrm{H} 3$ confirmed). We observed that the higher the LGO, the lesser the effect of mentoring on increasing ESE-OR.

As seen in Figure 1, entrepreneurs with low learning goal orientation develop ESE-OR through mentoring compared to those with higher learning goal orientation, whose effect appears to be null, and perhaps slightly negative. 
Table 3

Hierarchical Linear Regression of ESE-OR

\begin{tabular}{|c|c|c|c|c|c|}
\hline & $\begin{array}{c}\text { Model I } \\
\text { Std. } \beta\end{array}$ & $\begin{array}{c}\text { Model II } \\
\text { Std. } \beta\end{array}$ & $\begin{array}{l}\text { Model III } \\
\text { Std. } \beta\end{array}$ & $\begin{array}{l}\text { Model IV } \\
\text { Std. } \beta\end{array}$ & $\begin{array}{l}\text { Model V } \\
\text { Std. } \beta\end{array}$ \\
\hline Mentee's gender ${ }^{\mathrm{a}}$ & -0.003 & 0.010 & -0.028 & -0.038 & -0.050 \\
\hline Age & $-0.321 * * *$ & $-0.323 * * *$ & $-0.307 * * *$ & $-0.284 * * *$ & $-0.296 * * *$ \\
\hline Education & 0.030 & 0.026 & 0.046 & 0.042 & 0.030 \\
\hline Industry experience & 0.018 & 0.020 & 0.043 & 0.042 & 0.020 \\
\hline Management experience & $0.160^{*}$ & $0.161^{*}$ & $0.149 *$ & $0.144 *$ & $0.160^{*}$ \\
\hline Mentor experience ${ }^{b}$ & & -0.012 & -0.018 & -0.031 & -0.033 \\
\hline Industry dyad ${ }^{\mathrm{c}}$ & & -0.022 & -0.013 & -0.024 & -0.019 \\
\hline Mentor's gender ${ }^{\mathrm{a}}$ & & -0.048 & -0.040 & -0.052 & -0.033 \\
\hline LGO & & & $0.237 * * *$ & $0.238 * * *$ & $0.266^{* * *}$ \\
\hline Mentor functions & & & & $0.163^{*}$ & $0.197 * *$ \\
\hline LGO X Mentor functions & & & & & $-0.247 * * *$ \\
\hline Sig. variation $F$ & 0.000 & 0.888 & 0.000 & 0.012 & 0.000 \\
\hline $\mathrm{R}^{2}$ & 0.104 & 0.107 & 0.161 & 0.186 & 0.243 \\
\hline Adj. $R^{2}$ & 0.083 & 0.073 & 0.124 & 0.147 & 0.203 \\
\hline $\mathrm{n}$ & 219 & 219 & 219 & 219 & 219 \\
\hline \multicolumn{6}{|l|}{$\dagger=p \leq 0.10$} \\
\hline \multicolumn{6}{|l|}{$*=p \leq 0.05$} \\
\hline \multicolumn{6}{|l|}{$* *=p \leq 0.01$} \\
\hline \multicolumn{6}{|l|}{$* * *=p \leq 0.001$} \\
\hline \multicolumn{6}{|l|}{${ }^{\mathrm{a}} \mathrm{Men}=0$, Women $=1$} \\
\hline${ }^{\mathrm{b}}$ Non-entrepreneur $=0, \mathrm{E}$ & neur $=1$ & & & & \\
\hline${ }^{\mathrm{c}}$ Same industry $=0$, Differ & dustry $=1$ & & & & \\
\hline
\end{tabular}

Figure 1 - Interaction Between LGO and Mentor Functions

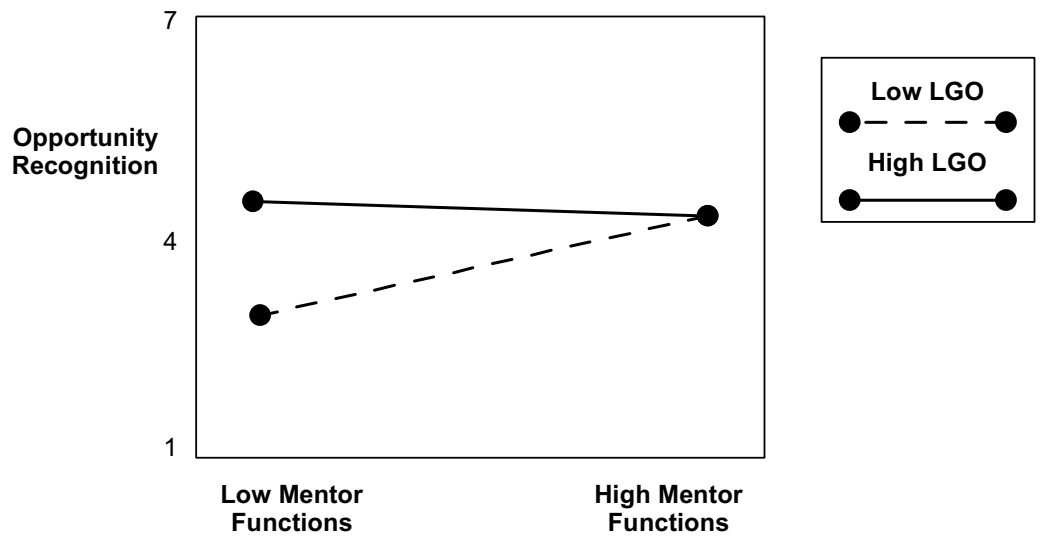




\section{Longitudinal analysis}

The GLM for repeated measures revealed the inter-subjects analysis of the impact of the independent variables on ESE-OR calculated at the mean. As we can see in Table 4, unsurprisingly, the same variables found significant at the cross-sectional analysis appear to be significantly related to ESE-OR, namely managerial experience $(F=5.611, p=0.020)$, mentor functions $(F=8.493, p=0.005)$, LGO $(F=5.513, p=0.021)$ and the interaction between being in a relationship with the mentor (or not) and LGO $(F=4.044, p=0.048)$. This further confirms H1, H2 and $\mathrm{H} 3$.

\section{Table 4}

Inter-Subjects Analysis for ESE-OR (mean calculated)

\begin{tabular}{|c|c|c|c|}
\hline & $F$ & Sig. $(p)$ & Eta-squared $\left(\eta^{2}\right)$ \\
\hline Constant & 57.110 & 0.000 & 0.429 \\
\hline Functions & 8.493 & 0.005 & 0.101 \\
\hline Managerial Exp. & 5.611 & 0.020 & 0.069 \\
\hline Age & 0.175 & 0.677 & 0.002 \\
\hline Education & 1.196 & 0.277 & 0.015 \\
\hline Relation $^{1}$ & 0.894 & 0.347 & 0.012 \\
\hline LGO & 5.513 & 0.021 & 0.068 \\
\hline \multirow[t]{2}{*}{ Relation * LGO } & 4.044 & 0.048 & 0.051 \\
\hline & 84 & & \\
\hline
\end{tabular}

${ }^{1}$ Active relationship with mentor in 2008=1; Relationship stopped in 2008 $=0$

The most relevant part of the analysis of change in ESE-OR is found at the intra-subjects contrast of GLM for repeated measures. Table 5 shows that the elapsed time between the data collections (3 years) does not significantly change the intra-level of ESE-OR in respondents $(F=0.525, p=0.471)$. To put it differently, our sample does not show any overall significant changes in the level of ESE-OR due to the effect of time. Furthermore, no control variables caused a change in ESE-OR, or any other direct effect such as still being in an active relationship with a mentor $(F=0.993, p=0.322)$ or on LGO $(F=0.064, p=0.801)$. However, the interaction of 
being in a relationship with a mentor (or not) and LGO caused ESE-OR to significantly change over the three-year period $(F=2.909, p=0.092)$. We considered $p \leq 0.10$ as relevant for this analysis instead of the traditional $p \leq 0.05$, mainly because of our small sample ( $\mathrm{n}=84$ ) that is divided by the analysis into two groups; those with an active relationship with a mentor, and those who had stopped, decreasing the power of the analysis and increasing Type II errors (Aguinis et al., 2010).

\section{Table 5}

Intra-Subjects Contrast for ESE-OR

\begin{tabular}{lccc}
\hline & $F$ & Sig. $(p)$ & Eta-squared $\left(\eta^{2}\right)$ \\
\hline Time (3 years) & 0.525 & 0.471 & 0.007 \\
Time * Functions & 1.920 & 0.170 & 0.025 \\
Time * Managerial Exp. & 0.076 & 0.784 & 0.001 \\
Time * Age $_{\text {Time * Education }}$ & 0.000 & 0.995 & 0.000 \\
Time * Relation $^{1}$ & 0.092 & 0.762 & 0.001 \\
Time * LGO $_{\text {Time * Relation * LGO }}$ & 0.993 & 0.322 & 0.013 \\
\hline & 0.064 & 0.801 & 0.001 \\
\hline
\end{tabular}

${ }^{1}$ Active relationship with mentor in 2008 $=1$; Relationship stopped in 2008 $=0$

With this result from the longitudinal analysis, we computed the interaction plots to highlight our findings. Figure 2 shows the effect of stopping a relationship with a mentor for those low on LGO. As we can see, low LGO mentees that stopped their relationship before the baseline survey (Time 1) had a decrease in ESE-OR in the three following years (Time 2) of 0.458 points on a 7 -point Likert scale (from 5.789 to 5.331). Low LGO mentees who were still in a relationship at Time 1 improved their ESE-OR by 0.199 over the three-year period (Time 2) (from 5.610 to 5.809). For the mentee entrepreneurs with high LGO (Figure 3), an active relationship at Time 1 decreased their ESE-OR by 0.268 points (from 5.896 to 5.628 ) at Time 2, and a terminated relationship decreased by 0.113 points (from 6.265 to 6.152 ) within the same 
period. Although the mentoring effect may have faded over time, especially for mentees whose relationship had already stopped at Time 1, these results show that mentoring is moderated by mentee LGO level, further confirming H3 with additional details.

Figure 2 - Effect of Time on Terminated or Active Relationships for Low LGO Mentees

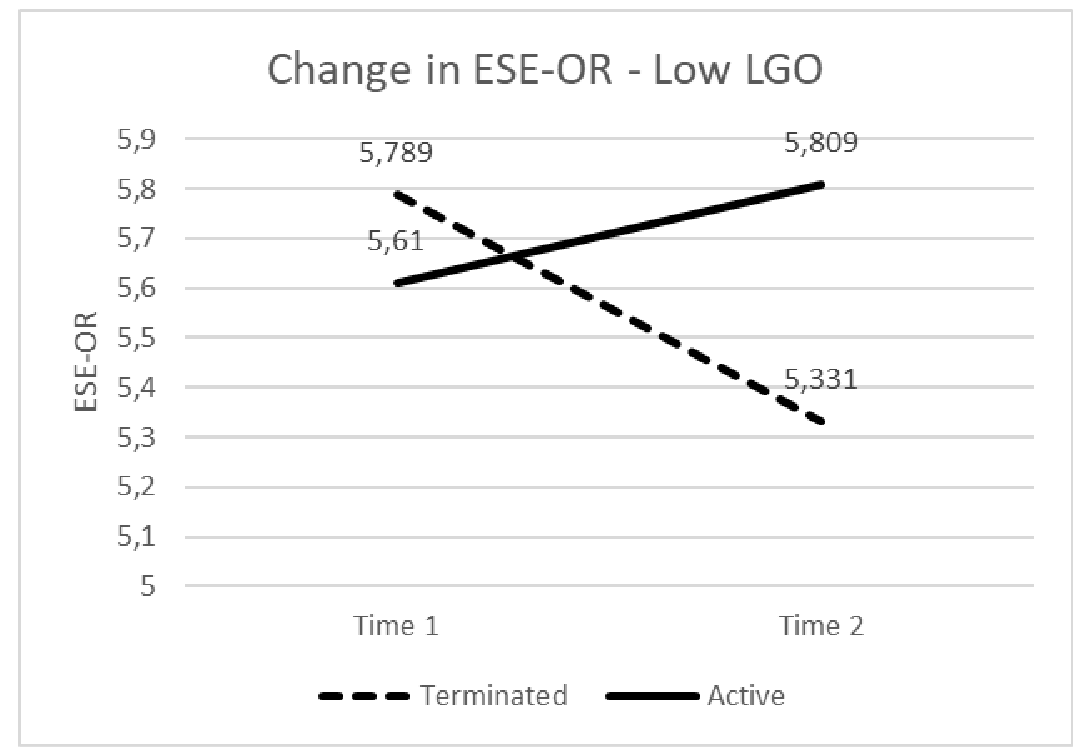

Figure 3 - Effect of Time on Terminated or Active Relationships for High LGO Mentees

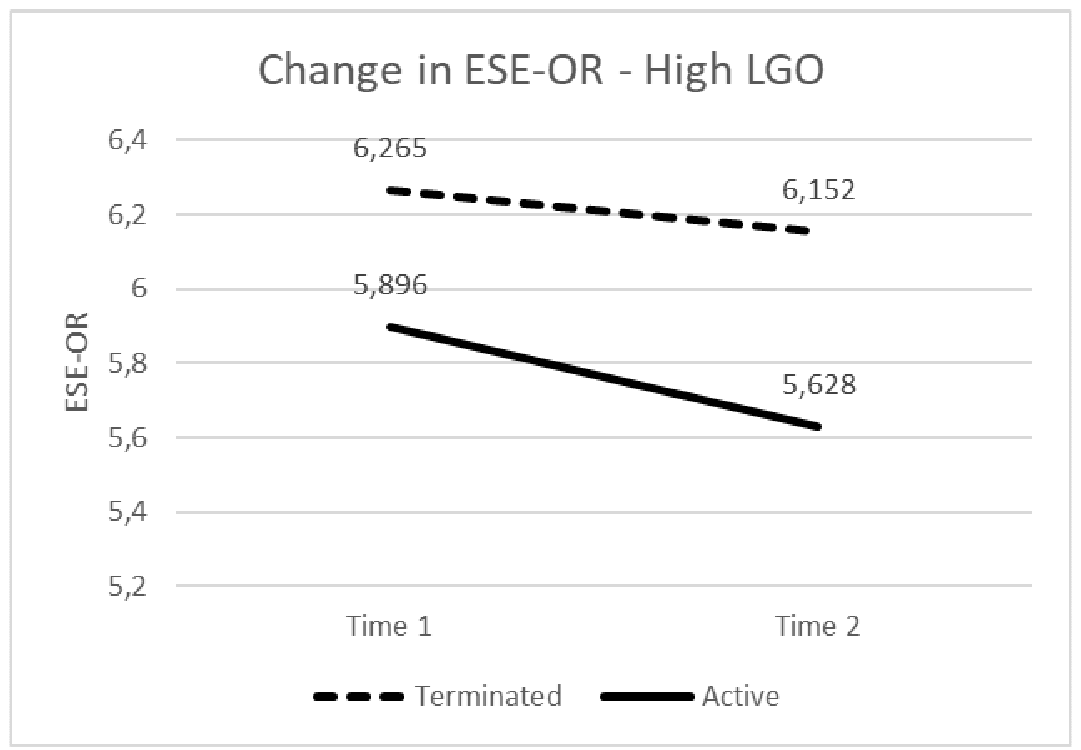




\section{Discussion}

Firstly, LGO in novice entrepreneurs is positively related to ESE-OR. Entrepreneurs with a stronger LGO may benefit from a wider variety of learning situations, which in turn provides more opportunities for self-efficacy development. These results are interesting on many levels. Although we cannot prove it here, it is likely that this disposition is useful for entrepreneurs, considering that learning is a fundamental dimension in entrepreneurship (Gibb, 1997; Minniti and Bygrave, 2001). As a mind-set that is relatively stable (Dweck, 2008; Dweck and Leggett, 1988; Elliott and Dweck, 1988), LGO may be an important construct in understanding entrepreneurship. Indeed, LGO explains how people will react after a failure or when facing difficulties (Diener and Dweck, 1978), by showing perseverance and commitment in learning, and in wanting to increase their own capacities. Our results may suggest the existence of a strong relation between LGO and the quest for feedback (Tuckey et al., 2002; VandeWalle, 2004; VandeWalle and Cummings, 1997), as the mean level of LGO for mentees is 6.24 (out of 7). However, another explanation for this high level of LGO may be that entrepreneurship as a career, with its many challenges and difficulties (Aspray and Cohoon, 2007; Grant, 2011), attracts individuals in a quest to learn and improve their capacities. It would be highly unlikely that strong LGO draws entrepreneurs towards mentoring, since a sample of non-entrepreneur mentees from another study presented a mean of 4.35 , and their mentors a mean of 4.38 using the exact same measure (Egan, 2005). Also, it is noteworthy that a high level of LGO combined with a high level of self-efficacy is likely to lead to an entrepreneurial career (Culbertson et al., 2011) and develop entrepreneurial intention (De Clercq et al., 2013). Thus, these facts lead us to suggest that high LGO may be an important aspect of the personality of individuals who choose an entrepreneurial career. Consequently, our contribution suggests that we should further understand 
how LGO attracts and retains individuals in an entrepreneurial career, and how it helps them achieve success.

Secondly, the longitudinal assessment regarding the change in ESE-OR highlights important contributions to entrepreneurship literature as well as organisations that support mentoring schemes. As shown in the results, as long as the mentoring relationship is ongoing, ESE-OR remains relatively high. However, the level of ESE-OR declines once the relationship ends. This finding is totally consistent with an experiment on nascent entrepreneur training that showed a short-term effect of training and support, but no long-term effect (Fairlie and Holleran, 2012). This is particularly true for novice entrepreneurs with the lowest LGO levels. This finding is important as it demonstrates that some entrepreneurs (with low LGO) may require more support than others, at least when ESE-OR needs to be enhanced. As opportunity recognition confidence (or ESE-OR) better explains the success of newly established firms versus human capital (Dimov, 2010), and since mentoring maintains ESE-OR at a high level, especially for lower LGO entrepreneurs, this suggests that mentoring can be a relevant support for the entrepreneur's success. Given that LGO can be an important disposition or mind-set (ref. Dweck, 2008) that entrepreneurs seem to exhibit when choosing this career (Culbertson et al., 2011), and based on our previous arguments and findings, mentoring can be more relevant to the success of entrepreneurs who are less suited for this type of career. More studies are needed in order to assess the impact of LGO in choosing entrepreneurship as a career, and in succeeding in the establishment of a viable business, but our results point in that direction and fulfil an important recently-highlighted research gap (Banerjee-Batist et al., 2019).

Thirdly, despite the previous proposition, it may be possible that mentees with high LGO, compared to those with low LGO, seek mentors more frequently. However, once the mentoring 
process has started, mentees with lower LGO benefit the most from the mentors' help. Therefore, the mentoring relationship improves their ESE-OR. Because of their differences in LGO, these two groups of mentees probably did not share the same motivations when entering the mentoring relationship. Mentees with low LGO seek approval concerning their entrepreneurial skills (reassurance motivation) and advice that will enable them to go beyond their perceived abilities (guidance motivation). Mentees with high LGO are likely to look for a relationship that will allow them to improve their skills by learning from their mentor's experience. When considering that high LGO trainees appear to benefit much more than low LGO trainees in a corporate entrepreneurship training context, our results that show declining ESE for high LGO mentee entrepreneurs would appear surprising (Byrne et al., 2016). At first glance, one would be tempted to advise high learning goal-oriented entrepreneurs to avoid being accompanied by a mentor, since doing so would (slightly) lower their level of entrepreneurial self-efficacy. However, additional research is needed in order to understand the impact of mentoring on the mentees' selfefficacy and the moderating role of individual variables. Previous studies have shown that some entrepreneurs are overly optimistic, and that this has a negative effect on the business's survival (Lowe and Ziedonis, 2006). Moreover, Hmieleski \& Baron (2008) demonstrated that a high level of self-efficacy has a negative effect on business performance when the entrepreneurs' level of optimism is high. Mentoring could then be useful for these entrepreneurs, since it brings ESE to a level closer to the entrepreneurs' real abilities (Tornikoski and Maalaoui, 2019). As previously noted, mentees with high LGO experience a higher level of self-efficacy when the mentors' functions are lower, but when the mentors' functions are fully exercised, the mentees' level of self-efficacy tends to lower and reach the same level of self-efficacy as mentees with low LGO. In other words, in an intense mentoring context (high mentor functions), all the mentees reported 
a very similar level of self-efficacy, whatever their level of LGO. It appears that mentoring standardises the level of ESE that can be developed, depending on the novice entrepreneur's level of LGO. This could reduce the errors committed by the mentees because of their excessive selfconfidence and increase the chances of business survival. This also suggests that they have a better assessment of their real competencies, which contributes to an important and overlooked issue in the literature (Bird, 2019).

Fourthly, results from this study confirm what previous studies have identified in that mentors play an important role in business opportunity recognition (Ozgen and Baron, 2007; Gordon, 2007; St-Jean et al., 2017), and especially regarding entrepreneurial self-efficacy in opportunity recognition. Mentor functions have a positive effect in this process, possibly through vicarious experiences, verbal persuasion, and physical and psychological states, as suggested by socio-cognitive learning theory (Bandura, 1997; Bandura, 1986). This is consistent with previous research that studied mentoring for entrepreneurs, as they showed an effect on ESE through interviews with mentees in an inductive-qualitative proof structure (Gravells, 2006; St-Jean and Audet, 2012; Sullivan, 2000; Kent et al., 2003). Our study goes further by following a deductivequantitative approach using larger samples, stronger measures, quantitative analysis, as well as using cross-sectional and longitudinal analyses combined. To our knowledge, this is the first hypothetical-deductive study that focuses on the effect of entrepreneurs' mentors regarding their self-efficacy in opportunity recognition with such a structured setting. Furthermore, contrary to all other studies in an entrepreneurship context, we measured the strength of mentoring received (mentor functions) instead of just comparing entrepreneurs supported by mentors versus others who were not (Ozgen and Baron, 2007). We contribute in showing that mentoring is much more than just role modelling. For example, mentors with previous experience in entrepreneurship, or 
who work in the same industry, do not have any effect on ESE-OR. Assuredly, people involved in business mentoring programmes have some kind of experience related to entrepreneurship, at least through working with entrepreneurs and understanding their reality. Thus, it seems that mentors support their mentee's ESE-OR by exercising mentor functions and not only because of past experience as entrepreneurs themselves. This gives credit to the effect of entrepreneurial role models in which there is a perceived similarity in the dyad (Ensher and Murphy, 1997), instead of real similarity as in same gender or previous experience (Bosma et al., 2012). Studies regarding mentoring relationships have found that once the mentor is chosen, real similarity is no longer important in developing mentoring outcomes (Madia and Lutz, 2004; Ensher et al., 2002; Turban et al., 2002). Our results show that real similarity with the mentor as role model does not have an impact on ESE-OR. In providing vicarious experiences and verbal persuasion, mentors can influence the mentee's ESE in opportunity recognition, thus being more than just specific role models for mentees (BarNir et al., 2011).

For organisations that support mentoring programmes for entrepreneurs, this study puts into perspective the fact that mentoring may be an important tool for supporting entrepreneurs. At the very least, it has been demonstrated that mentoring positively influences self-confidence in opportunity recognition. It has also been demonstrated that the effect of mentoring is particularly significant for entrepreneurs with low levels of LGO. Even for entrepreneurs with high levels of LGO, mentoring could help readjust their ESE to a more appropriate level, as over-optimism (and in this case, over-confidence in their skills) could have adverse effects. Furthermore, as long as the mentee chooses his or her mentor, the latter's previous entrepreneurship experience, or pairing within the same industry, does not have any effect on mentoring outcomes, at least not on ESE-OR. Thus, non-entrepreneur mentors are welcome, since they do not seem to affect the 
mentoring process. Pairing could also be done differently without any negative effects. Also, as some mentees may need to have long-term support from their mentor, the support offered should not be limited in time, but rather follow the needs of the novice entrepreneurs. Mentoring programme managers should be aware of this situation.

\section{Study limitations}

This study is not without certain limitations. Firstly, one must keep in mind that perceptual measures were used in this study. Thus, mentor functions are based on the mentee's assessment, rather than the mentor's perspective. As such, no mentors or any other individuals were interviewed, which only provides a partial picture of reality. Secondly, a control group of novice entrepreneurs with no mentor would also help to prove the effects of mentoring on the development of ESE in opportunity recognition, and verify whether LGO is high among those who do not choose mentoring. Thirdly, since mentoring includes learning as a major outcome (St-Jean and Audet, 2012; Sullivan, 2000) on one hand, and that learning includes both content and processes (ref. Politis, 2005) on the other hand, the effect of receiving additional information (Ucbasaran et al., 2009) or changing one's cognitive framework (Baron and Ensley, 2006) remain to be shown in order to better understand our results. In fact, it is possible that an increase in real opportunity recognition skills, through these processes, can influence ESE-OR. Thus, a better investigation that reflects the real capacity and its effect (rather than ESE) could be relevant. Fourthly, it should be noted that these results were obtained through the investigation of formal mentoring relationships. We are unable to confirm whether the same results could be replicated within an informal mentoring context. In fact, formal mentoring relationships appear at times to be less beneficial than informal ones (Baugh and Fagenson-Eland, 2007). Further investigation of an informal mentoring context would indeed be required. Fifthly, the context of mentoring has 
been excluded from this entire study and remains unexplored. As other researchers have suggested (Janssen et al., 2016), future research should also consider (or control for) other kinds of support that entrepreneurs receive and that could interact with mentoring, but also look at the reasons for seeking the support of a mentor, as well as the entire complex situation in which entrepreneurs are involved. Lastly, although the longitudinal results add weight to our findings, it should be noted that very few cases were used in some analyses, which could increase the frequency of type II errors, where the weak power of the test (caused by an insufficient number of cases) prevents the data from revealing an existing significant relationship. We also authorised the demonstration at a threshold of $p=0.092$ for the same reason (only 24 cases were used). Other longitudinal analyses with larger samples will be required. These are but a few of the many possible avenues for further research that would complete the findings and pursue additional investigations into these many dimensions.

\section{Conclusion}

In this study, we showed that entrepreneurial mentoring has a positive effect on entrepreneurial self-efficacy in opportunity recognition (ESE-OR), a key component in entrepreneurship behaviour. Moreover, we illustrated that this effect is not permanent, and that the learning goal orientation (LGO) had a moderating effect that makes entrepreneurs with low LGO increase their ESE-OR more than others, but that this effect decreased drastically when the mentoring relationship ended. This suggests the need for long-term support for entrepreneurs presenting low LGO in order to help them maintain high levels of entrepreneurial self-efficacy. This contributes to the body of research by highlighting LGO as an important mind-set that not 
only explains intention and behaviour in entrepreneurs, but also the impact of the support that entrepreneurs receive, and the potential learning outcomes that result from this support.

\section{Acknowledgements}

Authors wish to thank Per Davidsson for his thoughtful comments that helped improving this manuscript. They are also indebt to the two anonymous reviewers who provided many valuable remarks to improve the manuscript as well as Susan Marlow for her guidance throughout the revision process.

\section{Funding}

The author(s) disclosed receipt of the following financial support for the research, authorship, and/or publication of this article: The authors received financial support from the Social Sciences and Humanities Research Council of Canada (410-2010-2227).

\section{Author biographies}

Étienne St-Jean, holds the Canada Research Chair on Entrepreneurial Career at the Université du Québec at Trois-Rivières. He is a regular researcher of the Research Institute on SMEs, and the Scientific Director of the Entrepreneurship and Innovation Research Laboratory affiliated to CEI-Desjardins-UQTR.

Maripier Tremblay is Professor of Entrepreneurship at Université Laval (Québec, Canada). She holds a DBA (Doctorat in Business Admininistration) from Université du Québec à Trois-Rivières (UQTR). Her research interests include entrepreneurship education and support, responsible entrepreneurship and opportunity recognition.

\section{REFERENCES}

Aguinis H, Werner S, Abbott JL, et al. (2010) Customer-centric science: Reporting significant research results with rigor, relevance, and practical impact in mind. Organizational Research Methods 13: 515-539. 
Ahsan M, Zheng C, DeNoble A, et al. (2018) From Student to Entrepreneur: How Mentorships and Affect Influence Student Venture Launch. Journal of Small Business Management 56: $76-102$.

Ames C. (1992) Classrooms: Goals, structures, and student motivation. Journal of Educational Psychology 84: 261-271.

Ames C and Archer J. (1988) Achievement goals in the classroom: Students' learning strategies and motivation processes. Journal of Educational Psychology 80: 260-267.

Anna AL, Chandler GN, Jansen E, et al. (2000) Women business owners in traditional and nontraditional industries. Journal of business venturing 15: 279-303.

Ardichvili A, Cardozo RN and Ray S. (2003) A theory of entrepreneurial opportunity identification and development. Journal of business venturing 18: 105-123.

Arenius P and Clercq D. (2005) A network-based approach on opportunity recognition. Small Business Economics 24: 249-265.

Armstrong JS and Overton TS. (1977) Estimating nonresponse bias in mail surveys. Journal of Marketing Research 14: 396-402.

Aspray W and Cohoon JM. (2007) Positive illusions, motivations, management style, stress and psychological traits : A review of research literature on women's entrepreneurship in the information technology field. Boulder, CO: National Center for Women \& Information Technology - University of Colorado.

Baluku MM, Matagi L, Musanje K, et al. (2019) Entrepreneurial Socialization and Psychological Capital: Cross-Cultural and Multigroup Analyses of Impact of Mentoring, Optimism, and Self-Efficacy on Entrepreneurial Intentions. Entrepreneurship Education and Pedagogy 2: 5-42.

Bandura A. (1986) Social Foundations of Thought and Action - A Social Cognitive Theory, Englewood Cliffs, N.J.: Prentice-Hall.

Bandura A. (1997) Self-efficacy : the exercise of control, New York: W.H. Freeman.

Banerjee-Batist R, Reio Jr TG and Rocco TS. (2019) Mentoring functions and outcomes: an integrative literature review of sociocultural factors and individual differences. Human Resource Development Review 18: 114-162.

BarNir A, Watson WE and Hutchins HM. (2011) Mediation and Moderated Mediation in the Relationship Among Role Models, Self-Efficacy, Entrepreneurial Career Intention, and Gender. Journal of Applied Social Psychology 41: 270-297.

Baron RA. (2006) Opportunity Recognition as Pattern Recognition: How Entrepreneurs "Connect the Dots" to Identify New Business Opportunities. Academy of Management Perspectives 20: 104-119. 
Baron RA and Ensley MD. (2006) Opportunity Recognition as the Detection of Meaningful Patterns: Evidence from Comparisons of Novice and Experienced Entrepreneurs. Management Science 52: 1331-1344.

Baugh SG and Fagenson-Eland E. (2007) Formal mentoring programs: A "poor cousin" to informal relationships. In: Ragins BR and Kram KE (eds) The handbook of mentoring at work: Theory, research, and practice. Los Angeles, USA: Sage Publications, 249-271.

Bell BS and Kozlowski SWJ. (2002) Goal orientation and ability: Interactive effects on selfefficacy, performance, and knowledge. Journal of Applied Psychology 87: 497-505.

Bird B. (2019) Reflection on Entrepreneurial Competency. In: Katz JA and Corbett AC (eds) Seminal Ideas for the Next Twenty-Five Years of Advances. Emerald Publishing Limited, 133-140.

Bosma N, Hessels J, Schutjens V, et al. (2012) Entrepreneurship and role models. Journal of Economic Psychology 33: 410-424.

Bouquillon EA, Sosik JJ and Lee D. (2005) 'It's only a phase': examining trust, identification and mentoring functions received accross the mentoring phases. Mentoring \& Tutoring 13: 239-258.

Brodie J, Van Saane SH and Osowska R. (2017) Help wanted: Exploring the value of entrepreneurial mentoring at start-up. Industry and Higher Education 31: 122-131.

Burnette JL, O'Boyle EH, VanEpps EM, et al. (2013) Mind-sets matter: A meta-analytic review of implicit theories and self-regulation. Psychological Bulletin 139: 655-701.

Button SB, Mathieu JE and Zajac DM. (1996) Goal Orientation in Organizational Research: A Conceptual and Empirical Foundation. Organizational Behavior and Human Decision Processes 67: 26-48.

Byrne J, Delmar F, Fayolle A, et al. (2016) Training corporate entrepreneurs: an action learning approach. Small Business Economics 47: 479-506.

Byrne O and Shepherd DA. (2015) Different Strokes for Different Folks: Entrepreneurial Narratives of Emotion, Cognition, and Making Sense of Business Failure. Entrepreneurship Theory and Practice 39: 375-405.

Chandler GN and Hanks SH. (1994) Founder Competence, the Environment, and Venture Performance. Entrepreneurship: Theory \& Practice 19: 77-89.

Ciuchta MP, Letwin C, Stevenson R, et al. (2018) Betting on the coachable entrepreneur: signaling and social exchange in entrepreneurial pitches. Entrepreneurship Theory and Practice 42: 860-885.

Cope J. (2005) Toward a Dynamic Learning Perspective of Entrepreneurship. Entrepreneurship Theory and Practice 29: 373-397. 
Culbertson SS, Smith MR and Leiva PI. (2011) Enhancing entrepreneurship: The role of goal orientation and self-efficacy. Journal of Career Assessment 19: 115-129.

D'Abate CP, Eddy ER and Tannenbaum SI. (2003) What's in a name? A literature-based approach to understanding mentoring, coaching, and other constructs that describe developmental interactions. Human Resource Development Review 2: 360-384.

Davidsson P and Honig B. (2003) The role of social and human capital among nascent entrepreneurs. Journal of business venturing 18: 301-331.

Day R and Allen TD. (2004) The relationship between career motivation and self-efficacy with protégé career success. Journal of vocational behavior 64: 72-91.

De Clercq D, Honig B and Martin B. (2013) The roles of learning orientation and passion for work in the formation of entrepreneurial intention. International Small Business Journal 31: $652-676$.

DeNoble AF, Jung D and Ehrlich SB. (1999) Entrepreneurial self-efficacy: The development of a measure and its relationship to entrepreneurial action. Babson College Entrepreneurship Research Conference. Babson, MA: Babson College.

Diener CI and Dweck CS. (1978) An Analysis of Learned Helplessness: Continuous Changes in Performance, Strategy, and Achievement Cognitions Following Failure. Journal of Personality and Social Psychology 36: 451-462.

Dimov D. (2010) Nascent entrepreneurs and venture emergence: opportunity confidence, human capital, and early planning. Journal of Management Studies 47: 1123-1153.

Doern R and Goss D. (2014) The Role of Negative Emotions in the Social Processes of Entrepreneurship: Power Rituals and Shame-Related Appeasement Behaviors. Entrepreneurship Theory and Practice 38: 863-890.

Dupeyrat C and Mariné C. (2005) Implicit theories of intelligence, goal orientation, cognitive engagement, and achievement: A test of Dweck's model with returning to school adults. Contemporary Educational Psychology 30: 43-59.

Dweck C. (2008) Mindset: The new psychology of success, New-York: Ballantine Books.

Dweck CS. (1986) Motivational processes affection learning. American psychologist 41: 10401048.

Dweck CS and Leggett EL. (1988) A social-cognitive approach to motivation and personality. Psychological review 95: 256-273.

Eby LT, Butts M, Lockwood A, et al. (2004) Protégés' negative mentoring experiences: Construct development and nomological validation. Personnel Psychology 57: 411-447. 
Eby LT, McManus SE, Simon SA, et al. (2000) The Protege's Perspective Regarding Negative Mentoring Experiences: The Development of a Taxonomy. Journal of vocational behavior 57: 1-21.

Eesley C and Wang Y. (2017) Social influence in career choice: Evidence from a randomized field experiment on entrepreneurial mentorship. Research policy 46: 636-650.

Egan TM. (2005) The Impact of Learning Goal Orientation Similarity on Formal Mentoring Relationship Outcomes. Advances in Developing Human Resources 7: 489-504.

Elliott ES and Dweck CS. (1988) Goals: an approach to motivation and achievement. Journal of Personality and Social Psychology 54: 5-12.

Ensher EA, Grant-Vallone EJ and Marelich WD. (2002) Effects of Perceived Attitudinal and Demographic Similarity on Protégés' Support and Satisfaction Gained From Their Mentoring Relationships. Journal of Applied Social Psychology 32: 1407-1430.

Ensher EA and Murphy SE. (1997) Effects of Race, Gender, Perceived Similarity, and Contact on Mentor Relationships. Journal of vocational behavior 50: 460-481.

Fairlie RW and Holleran W. (2012) Entrepreneurship training, risk aversion and other personality traits: Evidence from a random experiment. Journal of Economic Psychology 33: 366378.

Garvey B. (2004) The mentoring/counseling/coaching debate: Call a rose by any other name and perhaps it's a bramble? Development and Learning in organizations 18: 6-8.

Ghosh R, Shuck B, Cumberland D, et al. (2019) Building Psychological Capital and Employee Engagement: Is Formal Mentoring a Useful Strategic Human Resource Development Intervention? Performance Improvement Quarterly 32: 37-54.

Gibb AA. (1997) Small Firms' Training and Competitiveness. Building Upon the Small Business as a Learning Organisation. International Small Business Journal 15: 13-29.

Godshalk VM and Sosik JJ. (2003) Aiming for career success: The role of learning goal orientation in mentoring relationships. Journal of vocational behavior 63: 417-437.

Goodman JS and Blum TC. (1996) Assessing the non-random sampling effects of subject attrition in longitudinal research. Journal of Management 22: 627-652.

Gordon SP and Brobeck SR. (2010) Coaching the mentor: Facilitating reflection and change. Mentoring \& Tutoring: Partnership in Learning 18: 427-447.

Gordon SR. (2007) Interpersonal trust, vigilance and social networks roles in the process of entrepreneurial opportunity recognition. International Journal of Entrepreneurship and Small Business 4: 564-585. 
Grant S. (2011) On being entrepreneurial: the highs and lows of entrepreneurship. In: LanganFox J and Cooper CL (eds) Handbook of Stress in the Occupations. Edward Elgar Publishing, 359-384.

Gravells J. (2006) Mentoring start-up entrepreneurs in the East Midlands - Troubleshooters and trusted friends. The International Journal of Mentoring and Coaching 4: 3-23.

Haggard DL, Dougherty TW, Turban DB, et al. (2011) Who Is a Mentor? A Review of Evolving Definitions and Implications for Research. Journal of Management 37: 280-304.

Haimovitz K, Wormington SV and Corpus JH. (2011) Dangerous mindsets: How beliefs about intelligence predict motivational change. Learning and Individual Differences 21: 747752.

Heppen JB, Zeiser K, Holtzman DJ, et al. (2018) Efficacy of the Check \& Connect mentoring program for at-risk general education high school students. Journal of Research on Educational Effectiveness 11: 56-82.

Hmieleski KM and Baron RA. (2008) When does entrepreneurial self-efficacy enhance versus reduce firm performance? Strategic Entrepreneurship Journal 2: 57-72.

Homer. (1999) The Odyssey of Homer, New-York, USA.: Harper Perennial Modern Classics.

Janssen S, van Vuuren M and de Jong MD. (2016) Informal mentoring at work: A review and suggestions for future research. International Journal of Management Reviews 18: 498517.

Johannisson B. (1991) University training for entrepreneurship: a Swedish approach. Entrepreneurship and Regional Development 3: 67-82.

Jyoti J and Sharma P. (2015) Impact of mentoring functions on career development: moderating role of mentoring culture and mentoring structure. Global Business Review 16: 700-718.

Kent T, Dennis C and Tanton S. (2003) An evaluation of mentoring for SME retailers. International Journal of Retail \& Distribution Management 31: 440-448.

Korkeila K, Suominen S, Ahvenainen J, et al. (2001) Non-response and related factors in a nation-wide health survey. European journal of epidemiology 17: 991-999.

Kornelsen J. (2018) Facilitating Academic Entrepreneurial Education and Entrepreneurship through Professorial Mentoring. Academy of Management Global Proceedings.

Kram KE. (1985) Mentoring at work : Developmental relationships in organizational life Glenview, IL: Scott Foresman.

Kram KE and Hall DT. (1989) Mentoring as an antidote to stress during corporate trauma. Human Resource Management 28: 493-510. 
Kubberød E, Fosstenløkken SM and Erstad PO. (2018) Peer mentoring in entrepreneurship education: towards a role typology. Education + Training 60: 1026-1040.

Levesque LL, O'Neill RM, Nelson T, et al. (2005) Sex differences in the perceived importance of mentoring functions. Career Development International 10: 429-444.

Locke EA and Latham GP. (1990) A theory of goal setting \& task performance: Prentice-Hall, Inc.

Lowe RA and Ziedonis AA. (2006) Overoptimism and the performance of entrepreneurial firms. Management Science 52: 173-186.

Lukosiute K, Jensen S and Tanev S. (2019) Is Joining a Business Incubator or Accelerator Always a Good Thing? Technology Innovation Management Review 9: 5-15.

Madia BP and Lutz CJ. (2004) Perceived Similarity, Expectation-Reality Discrepancies, and Mentors' Expressed Intention to Remain in Big Brothers/Big Sisters Programs. Journal of Applied Social Psychology 34: 598-623.

Marlow S and McAdam M. (2012) Analyzing the influence of gender upon high-technology venturing within the context of business incubation. Entrepreneurship Theory and Practice 36: 655-676.

Maurer TJ. (2001) Career-relevant learning and development, worker age, and beliefs about selfefficacy for development. Journal of Management 27: 123-140.

McGee J, Peterson M, Mueller S, et al. (2009) Entrepreneurial Self Efficacy: Refining the Measure. Entrepreneurship Theory and Practice 33: 965-988.

McGowan P, Cooper S, Durkin M, et al. (2015) The influence of social and human capital in developing young women as entrepreneurial business leaders. Journal of Small Business Management 53: 645-661.

McKevitt D and Marshall D. (2015) The legitimacy of entrepreneurial mentoring. International Journal of Entrepreneurial Behavior \& Research 21: 263-280.

Minniti M and Bygrave W. (2001) A Dynamic Model of Entrepreneurial Learning. Entrepreneurship: Theory \& Practice 25: 5-16.

Mitchell JR and Shepherd DA. (2010) To thine own self be true: Images of self, images of opportunity, and entrepreneurial action. Journal of business venturing 25: 138-154.

Mueller SL and Dato-On MC. (2008) Gender-role orientation as a determinant of entrepreneurial self-efficacy. Journal of Developmental Entrepreneurship 13: 3-20.

Nabi G, Walmsley A and Akhtar I. (Online First) Mentoring functions and entrepreneur development in the early years of university. Studies in Higher Education. 
Newman A, Obschonka M, Schwarz S, et al. (2019) Entrepreneurial self-efficacy: A systematic review of the literature on its theoretical foundations, measurement, antecedents, and outcomes, and an agenda for future research. Journal of vocational behavior 110: 403419.

Nowiński W and Rialp A. (2016) The impact of social networks on perceptions of international opportunities. Journal of Small Business Management 54: 445-461.

Ozgen E and Baron RA. (2007) Social sources of information in opportunity recognition: Effects of mentors, industry networks, and professional forums. Journal of business venturing 22: 174-192.

Park JH, Newman A, Zhang L, et al. (2016) Mentoring functions and turnover intention: The mediating role of perceived organizational support. The International Journal of Human Resource Management 27: 1173-1191.

Patzelt H and Shepherd DA. (2011) Negative emotions of an entrepreneurial career: Selfemployment and regulatory coping behaviors. Journal of business venturing 26: 226-238.

Pellegrini EK and Scandura TA. (2005) Construct equivalence across groups: an unexplored issue in mentoring research. Educational and Psychological Measurement 65: 323-335.

Pintrich PR. (2000) The role of goal orientation in self-regulated learning. In: Boekaerts M, Pintrich PR and Zeidner M (eds) Handbook of self-regulation. San-Diego, CA: Academic Press, 451-502.

Pintrich PR and Schunk DH. (1996) The role of expectancy and self-efficacy beliefs. In: Pintrich PR and Schunk DH (eds) Motivation in Education: Theory, Research \& Applications. Englewood Cliffs, N.J.: Merrill.

Podsakoff PM, MacKenzie SB, Lee JY, et al. (2003) Common method biases in behavioral research: A critical review of the literature and recommended remedies. Journal of Applied Psychology 88: 879-903.

Politis D. (2005) The Process of Entrepreneurial Learning: A Conceptual Framework. Entrepreneurship Theory and Practice 29: 399-424.

Powers LE, Sowers J-A and Stevens T. (1995) An Exploratory, Randomized Study of the Impact of Mentoring on the Self-Efficacy and Community-Based Knowledge of Adolescents with Severe Physical Challenges. Journal of Rehabilitation 61: 33-42.

Preston JM, Prieto-Flores Ò and Rhodes JE. (2019) Mentoring in context: A comparative study of youth mentoring programs in the United States and continental Europe. Youth \& Society 51: 900-914. 
Radu Lefebvre M and Redien-Collot R. (2013) "How to Do Things with Words": The Discursive Dimension of Experiential Learning in Entrepreneurial Mentoring Dyads. Journal of Small Business Management 51: 370-393.

Ragins BR, Cotton JL and Miller JS. (2000) Marginal mentoring: The effects of type of mentor, quality of relationship, and program design on work and career attitudes. Academy of Management Journal 43: 1177-1184.

Ramos-Rodriguez A-R, Medina-Garrido J-A, Lorenzo-Gómez J-D, et al. (2010) What you know or who you know? The role of intellectual and social capital in opportunity recognition. International Small Business Journal 28: 566-582.

Scandura TA and Williams EA. (2001) An investigation of the moderating effects of gender on the relationships between mentorship initiation and protégé perceptions of mentoring functions. Journal of vocational behavior 59: 342-363.

Schmitt A, Rosing K, Zhang SX, et al. (2018) A dynamic model of entrepreneurial uncertainty and business opportunity identification: exploration as a mediator and entrepreneurial self-efficacy as a moderator. Entrepreneurship Theory and Practice 42: 835-859.

Schmutzler J, Andonova V and Diaz-Serrano L. (2019) How Context Shapes Entrepreneurial Self-Efficacy as a Driver of Entrepreneurial Intentions: A Multilevel Approach. Entrepreneurship Theory and Practice 43: 880-920.

Secundo G, Schiuma G and Passiante G. (2017) Entrepreneurial learning dynamics in knowledge-intensive enterprises. International Journal of Entrepreneurial Behavior \& Research 23: 366-380.

Shane SA. (2000) Prior knowledge and the discovery of entrepreneurial opportunities. Organization Science 11: 448-469.

Shane SA and Venkataraman S. (2000) The promise of entrepreneurship as a field of research. Academy of management review 25: 217-226.

Shepherd DA and DeTienne DR. (2005) Prior knowledge, potential financial reward, and opportunity identification. Entrepreneurship Theory and Practice 29: 91-112.

Simon SA and Eby LT. (2003) A typology of negative mentoring experiences: A multidimensional scaling study. Human Relations 56: 1083-1109.

Singh P and Kumar K. (2019) E-Mentoring: Alternative paradigm for entrepreneurial aptitude development. Academy of Entrepreneurship Journal 25: 1-9.

Sosik JJ and Godshalk VM. (2000) Leadership styles, mentoring functions received, and job-related stress: a conceptual model and preliminary study. Journal of organizational behavior 21: 365-390. 
Spector PE. (2006) Method variance in organizational research - Truth or urban legend? Organizational Research Methods 9: 221-232.

Spector PE and Brannick MT. (2011) Methodological urban legends: The misuse of statistical control variables. Organizational Research Methods 14: 287-305.

Spoth R, Goldberg C and Redmond C. (1999) Engaging families in longitudinal preventive intervention research: Discrete-time survival analysis of socioeconomic and socialemotional risk factors. Journal of consulting and clinical psychology 67: 157-163.

St-Jean E. (2011) Mentor functions for novice entrepreneurs. Academy of Entrepreneurship Journal 17: 65-84.

St-Jean E and Audet J. (2012) The role of mentoring in the learning development of the novice entrepreneur. International Entrepreneurship and Management Journal 8: 119-140.

St-Jean E and Audet J. (2013) The Effect of Mentor Intervention Style in Novice Entrepreneur Mentoring Relationships. Mentoring \& Tutoring: Partnership in Learning 21: 96-119.

St-Jean E, Radu-Lefebvre M and Mathieu C. (2018) Can less be more? Mentoring functions, learning goal orientation, and novice entrepreneurs' self-efficacy. International Journal of Entrepreneurial Behavior \& Research 24: 2-21.

St-Jean E, Tremblay M, Janssen F, et al. (2017) May Business Mentors Act as Opportunity Brokers and Enablers Among University Students? International Entrepreneurship and Management Journal 13: 97-111.

Stevenson L. (1986) Against all odds: The entrepreneurship of women. Journal of Small Business Management 24: 30-37.

Sullivan R. (2000) Entrepreneurial learning and mentoring. International Journal of Entrepreneurial Behavior \& Research 6: 160-175.

Sullivan SE, Forret ML, Mainiero LA, et al. (2007) What motivates entrepreneurs? An exploratory study of the kaleidoscope career model and entrepreneurship. Journal of Applied Management and Entrepreneurship 12: 4-19.

Tabachnick BG and Fidell LS. (2007) Using Multivariate Statistics, Boston, MA: Allyn \& Bacon.

Talbot D, Denny J and Henderson S. (2018) 'Trying to decide... what sort of teacher I wanted to be': mentoring as a dialogic practice. Teaching Education 29: 47-60.

Ting SX, Feng L and Qin W. (2017) The effect of entrepreneur mentoring and its determinants in the Chinese context. Management Decision 55: 1410-1425. 
Tornikoski E and Maalaoui A. (2019) Critical reflections-The Theory of Planned Behaviour: An interview with Icek Ajzen with implications for entrepreneurship research. International Small Business Journal 37: 536-550.

Tuckey M, Brewer N and Williamson P. (2002) The influence of motives and goal orientation on feedback seeking. Journal of Occupational and Organizational Psychology 75: 195-216.

Turban DB, Dougherty TW and Lee FK. (2002) Gender, Race, and Perceived Similarity Effects in Developmental Relationships: The Moderating Role of Relationship Duration. Journal of vocational behavior 61: 240-262.

Ucbasaran D, Westhead P and Wright M. (2009) The extent and nature of opportunity identification by experienced entrepreneurs. Journal of business venturing 24: 99-115.

Unger JM, Rauch A, Frese M, et al. (2011) Human capital and entrepreneurial success: A metaanalytical review. Journal of business venturing 26: 341-358.

Uy MA, Sun S and Foo M-D. (2017) Affect spin, entrepreneurs' well-being, and venture goal progress: The moderating role of goal orientation. Journal of business venturing 32: 443460.

VandeWalle D. (2004) A goal orientation model of feedback-seeking behavior. Human resource management review 13: 581-604.

VandeWalle D and Cummings LL. (1997) A test of the influence of goal orientation on the feedback-seeking process. Journal of Applied Psychology 82: 390-400.

Wanberg CR, Welsh ET and Hezlett SA. (2003) Mentoring research: A review and dynamic process model. In: Martocchio JJ and Ferris GR (eds) Research in personnel and human resources management. Oxford, UK: Elsevier Science Ltd., 39-124.

Welpe IM, Spörrle M, Grichnik D, et al. (2012) Emotions and opportunities: the interplay of opportunity evaluation, fear, joy, and anger as antecedent of entrepreneurial exploitation. Entrepreneurship Theory and Practice 36: 69-96.

Whyte G, Saks AM and Hook S. (1997) When success breeds failure: the role of self-efficacy in escalating commitment to a losing course of action. Journal of organizational behavior 18: $415-432$.

Williams FS, Scott ES, Tyndall DE, et al. (2018) New Nurse Graduate Residency Mentoring: A Retrospective Cross-Sectional Research Study Nurse residency programs. Nursing Economics 36: 121-128.

Wilson F, Kickul J, Marlino D, et al. (2009) An analysis of the role of gender and self-efficacy in developing female entrepreneurial interest and behavior. Journal of Developmental Entrepreneurship 14: 105-119. 